\title{
Rede urbana e divisão territorial do trabalho: uma análise das cadeias do tabaco e da avicultura na Região dos Vales-Rio Grande do Sul
}

\author{
Urban network and territorial division of labour: an analysis of the tobacco and poultry \\ productive chains in the Vales Region-Rio Grande do Sul
}

\begin{abstract}
Carolina Rezende Faccin
Arquiteta e urbanista, Mestre e Doutoranda em Planejamento Urbano e Regional Programa de Pós-Graduação em Planejamento Urbano e Regional, UFRGS, Brasil faccincarolina@gmail.com

Rogério Leandro Lima da Silveira Geógrafo, Doutor em Geografia Humana Programa de Pós-Graduação em Desenvolvimento Regional, UNISC, Brasil $\underline{\text { rlls@,unisc.br }}$
\end{abstract}

\begin{abstract}
Resumo
A globalização é responsável por uma ampliação das interações, contribuindo para configuração de complexos globalizados movidos pela distribuição e integração espacial de atividades produtivas e pelas estratégias de corporações que atuam em diferentes escalas espaciais. A divisão territorial do trabalho dessas cadeias produtivas globais condiciona e reflete o funcionamento das redes urbanas. Analisa-se a divisão territorial do trabalho das cadeias do tabaco e da avicultura, comandadas por corporações multinacionais, e suas interrelações com a rede urbana no território da região dos ValesRS-Brasil. Utiliza-se dados do Censo Demográfico (IBGE, 2010), da rede urbana brasileira (IBGE, 2020b) e dos CNPJ das empresas (2020). Observa-se que as empresas multilocalizadas e verticalizadas no território, como as multinacionais, constituem padrões espaciais mais simples de interações na rede urbana, enquanto as empresas multilocalizadas e horizontalizadas, como as de abrangência regional, constituem padrões mais complexos.
\end{abstract}

Palavras-chave: Rede urbana; Divisão territorial do trabalho; Tabaco; Avicultura; Região dos Vales-RS.

\begin{abstract}
Globalization is responsible for an expansion of interactions, contributing to the configuration of globalized complexes driven by the spatial distribution of productive activities and the strategies of corporations that operate at different spatial scales. The territorial division of labour in these global production chains conditions and reflects the functioning of urban networks. The territorial division of labour of the tobacco and poultry chains, commanded by multinational corporations, and their interrelationships with the urban network in the territory of the Vales region-RS-Brazil is analyzed. Data from the Demographic Census (IBGE, 2010), the urban network (IBGE, 2018) and the CNPJ of the companies (2020) are used. It is observed that multi-localized and verticalized companies in the territory, such as multinationals, constitute simpler spatial patterns of interactions in the urban network, while multi-localized and horizontalized companies, such as those with a regional scope, constitute more complex patterns.
\end{abstract}

Keywords: Urban network; Territorial division of labour; Tobacco; Poultry farming; Vales regionRS. 


\section{INTRODUÇÃO}

Até meados do século XX a produção agroindustrial se realizava em cadeias curtas (desde a atividade primária até o consumo), operando em espaços geográficos limitados e pouco articulados entre si. No entanto, no período atual, a globalização tem sido responsável por uma ampliação das interações, contribuindo para a configuração de complexos globalizados movidos pela distribuição espacial e pelas estratégias das grandes corporações globais. Da mesma forma, a exigência permanente dos atores hegemônicos em garantir, cada vez mais, maior fluidez no espaço aos seus fluxos, tem resultado na ampliação e na complexificação da divisão territorial do trabalho e das diversas formas de circulação. O que tem sido condicionada e refletida através da rede urbana (CORRÊA, 2006; ARROYO; DA CRUZ, 2015).

Este artigo busca analisar a divisão territorial do trabalho das cadeias produtivas do tabaco e da avicultura, comandadas por corporações multinacionais, e suas interrelações com as redes urbanas regionais na escala do território da região dos Vales, no Rio Grande do Sul - Brasil. Além disso, busca-se identificar como ocorre a divisão territorial do trabalho nas cadeias produtivas do tabaco e da produção de frango na região dos Vales e como elas repercutem na dinâmica de funcionamento da rede urbana regional.

A análise da dinâmica relacional entre a rede urbana regional e a divisão territorial do trabalho (DTT) dessas duas cadeias produtivas é realizada no recorte espacial da região dos Vales, na zona centro-oriental do Rio Grande do Sul. O território regional é formado pelas sub-regiões contíguas do Vale do Rio Pardo, especializada na produção do tabaco em folha, e do Vale do Taquari, onde predomina a produção da carne de frango na economia regional.

A DTT dessas cadeias produtivas na região é constituída por diferentes etapas e setores econômicos: desde a produção primária realizada em pequenas propriedades rurais, passando pelas diversas empresas fornecedoras de insumos variados de apoio à produção agrícola e industrial, envolvendo também empresas de transporte, processamento industrial, instituições financeiras e de seguros, e ainda empresas de logística e exportação. A DTT existente em cada uma dessas cadeias apresenta particularidades e se realiza articulando diferentes lugares e cidades da própria região e de fora dela, promovendo uma dinâmica desigual de fluxos de pessoas, capital, produtos e informações na rede urbana regional, sob o comando das empresas multinacionais que atuam na região.

Metodologicamente, analisa-se a distribuição espacial dessas empresas, suas atuações nas respectivas DTT e as relações entre suas matrizes e filiais, com base nos dados do Censo Demográfico do Instituto Brasileiro de Geografia e Estatística (IBGE) (2010); da produção agrícola municipal de tabaco e de carne de frango (IBGE, 2018a; 2018b); dos fluxos da Região de Influência das Cidades REGIC - 2018 (IBGE, 2020b); nos dados do Cadastro Nacional da Pessoa Jurídica (CNPJ) das 
empresas existentes na região de estudo (RECEITA FEDERAL, 2019); no registro de estabelecimentos do Ministério da Ministério da Agricultura, Pecuária e Abastecimento (MAPA) (2020) e em dados da Relação Anual de Informações Sociais (RAIS) (2018) e Cadastro Geral de Empregados e Desempregados (CAGED) (2018). Por fim, o tratamento e análise dos dados foi feito através da confecção tabelas no e de mapas temáticos, através do programa de georreferenciamento QGis, e finalizados livremente no programa de tratamento de imagens vetorizadas Adobe Illustrator. A análise e crítica dos resultados obtidos foi realizada com base no referencial teórico adotado.

Esta pesquisa busca contribuir nos estudos sobre a divisão territorial do trabalho e suas interrelações com a rede urbana. A análise da rede urbana é essencial para se compreender relações econômicas e espaciais, de dependência, de articulação territorial, nas escalas regional e nacional. As empresas multinacionais e multilocalizadas que atuam na organização e funcionamento da DTT das cadeias produtivas agroindustriais, exercem grande influência, através da sua lógica de organização espacial, na dinâmica de desenvolvimento dos territórios e no funcionamento das redes urbanas regionais. A escolha do recorte espacial se justifica por ser uma região com economia regional verticalmente integrada aos mercados globais do tabaco e da carne de frango, e cuja dependência, através das suas particulares lógicas de organização espacial, impõe reflexos e condicionantes ao funcionamento da DTT ao grau de policentralidade da rede urbana regional, bem como oferece desafios ao processo de planejamento regional.

O trabalho, além dessa introdução, está estruturado em três partes principais. Na primeira, apresenta-se sinteticamente os fundamentos teóricos e conceituais da presente contribuição, destacando os conceitos de rede urbana, divisão territorial do trabalho e corporações multinacionais, através principalmente dos aportes de Milton Santos e Roberto Lobato Corrêa. Na segunda parte, busca-se caracterizar a região dos Vales e apresentar a configuração da sua rede urbana. Em uma terceira parte, analisa-se a divisão territorial do trabalho e as interações espaciais do tipo matriz-filial das empresas selecionadas no espaço regional, identificando-se as principais semelhanças e particularidades entre as duas cadeias produtivas e suas respectivas divisões territoriais do trabalho. Por fim, são apresentadas as considerações finais.

\section{REDE URBANA, DIVISÃO TERRITORIAL DO TRABALHO E CORPORAÇÕES MULTINACIONAIS}

No Brasil, Roberto Lobato Corrêa e Milton Santos muito contribuíram na discussão sobre a temática acerca da rede urbana, sobretudo nos anos de 1960, 1970 e início de 1990, analisando a rede urbana brasileira e suas metamorfoses diante das transformações estruturais que ocorreram no país a partir de meados do século XX (RODRIGUES; SILVA, 2007). Além disso, em âmbito nacional, 
diversas pesquisas estudam o comportamento da rede urbana, destacando-se aquelas desenvolvidas pelo IBGE, denominadas de Região de Influência das Cidades (REGIC).

A rede urbana, conforme Corrêa (2006, p. 29) "é entendida como o conjunto de centros, hierarquizados ou funcionalmente especializados e com diversas dimensões demográficas, articulados entre si, via fluxos materiais e não materiais". Ainda, por meio da rede urbana, o sistema de centros urbanos estabelece relações de subordinação, influência e complementaridade entre si.

A partir de 1800, com a intensificação do processo de urbanização em virtude do surgimento das sociedades industriais, a rede urbana estabelecida entre esses centros urbanos recém-formados passou a ser o meio através do qual a produção, circulação e o consumo se realizaram efetivamente. Nesse contexto, "por meio da rede urbana e da crescente rede de comunicações a ela vinculada, distantes regiões puderam ser articuladas, estabelecendo-se uma economia mundial" (Corrêa, 2006, p. 15).

Corrêa (2006, p. 26) aponta que a rede urbana é um reflexo da divisão territorial do trabalho, "na medida em que, em razão de vantagens locacionais diferenciadas, verifica-se uma hierarquia urbana e uma especialização funcional" entre os centros urbanos. Além disso, a rede urbana é uma condição para a divisão territorial do trabalho, já que, por meio dela e através das funções articuladas de suas cidades, se tornam viáveis a produção das diversas áreas agropastoris e sua própria produção industrial; a circulação entre as cidades; e o consumo nelas (Grifos nossos). Por conta disso, "é via rede urbana que o mundo pode tornar-se, simultaneamente, desigual e integrado" (CORRÊA, 2006, p. 26).

Corrêa (2006, p. 27) ainda destaca o papel das corporações multifuncionais e multilocalizadas na rede urbana:

\footnotetext{
A rede urbana é um reflexo, na realidade, dos efeitos acumulados da prática de diferentes agentes sociais, sobretudo as grandes corporações multifuncionais e multilocalizadas que, efetivamente, introduzem, tanto na cidade como no campo, atividades que geram diferenciações entre os centros urbanos. Diferenciações que, por sua vez, condicionam novas ações.
}

A rede urbana também serve de intermediação de decisões externas à rede. Por exemplo, através da atuação de subsidiárias de multinacionais em países subdesenvolvidos, a rede urbana intermedia fluxos advindos das sedes dessas empresas nos denominados países centrais. Por meio disso, a rede urbana se insere também na divisão internacional do trabalho (CORRÊA, 2006).

Por sua vez, a divisão territorial do trabalho pode ser entendida como uma categoria analítica interna da noção de espaço (SANTOS, 1996) e tanto ela, quanto a noção de rede urbana, são importantes para o entendimento do desenvolvimento regional e urbano (FRESCA, 2010). 
A divisão territorial do trabalho é, conforme Santos (1996, p. 139) “considerada como a repartição (ou no Mundo, ou no Lugar) do trabalho vivo. Essa distribuição, vista através da localização dos seus diversos elementos, é chamada de divisão territorial do trabalho." Complementarmente, Fresca (2010, p. 119-120) indica que "a divisão territorial do trabalho é fruto da diferenciação interna do espaço provocada pela expansão do capital”.

De acordo com Santos (1996, p. 139), “as feições naturais do território, cuja influência era determinante no início da história, têm, ainda hoje, influência sobre a maneira como se dá a divisão do trabalho". Assim, o entendimento da formação histórica de um dado espaço auxilia a compreender a sua atual divisão territorial do trabalho.

Além das formas naturais, o meio ambiente construído também se configura como uma forma herdada, condição para novas práticas em um dado território (SANTOS, 1996). Assim, uma plantação, um porto, uma estrada, a densidade ou a distribuição populacional são condições preexistentes, além de elementos que nos auxiliam a entender a estrutura hierárquica da rede urbana, e que condicionam e refletem a divisão territorial do trabalho.

Outro condicionante para a configuração da atual divisão territorial do trabalho, são as chamadas rugosidades, conceito desenvolvido por Milton Santos (1996, p. 140), que são o que "fica do passado como forma, espaço construído, paisagem, o que resta do processo de supressão, acumulação, superposição, com que as coisas se substituem e acumulam em todos os lugares.” Nesse sentido,

O trabalho já feito se impõe sobre o trabalho a fazer. A atual repartição territorial do trabalho repousa sobre as divisões territoriais do trabalho anteriores. E a divisão social do trabalho não pode ser explicada sem a explicação da divisão territorial do trabalho, que depende, ela própria, das formas geográficas herdadas (SANTOS, 1996, p. 141).

O espaço geográfico pode ser compreendido como uma acumulação desigual de tempos (SANTOS, 1996), revelando a coexistência entre diferentes temporalidades em um mesmo lugar, região ou território. Conforme Milton Santos (1996, p. 136), “cada lugar, cada subespaço, assiste, como testemunha e como ator ao desenrolar simultâneo de várias divisões do trabalho", seja porque em cada momento histórico muda a divisão do trabalho, seja porque cada agente promove sua própria divisão do trabalho. Importa aqui reconhecer que "cada lugar é teatro de tempos externos múltiplos" (SANTOS, 1996, p. 139).

Assim, verifica-se que as redes urbanas e a divisão territorial do trabalho são um caminho para discutir e interpretar relações entre cidades, em diferentes escalas. Isso tem tido grande importância no atual cenário global de complexas interações, mediante a emergência do meio técnicocientífico-informacional (SANTOS, 1996), demandando progressiva demanda pela superação do espaço pelo tempo, e crescente articulação de empresas multilocalizadas nacional e internacionalmente. 
A superação do espaço pelo tempo, através dos meios de circulação e comunicação, contribuiu para a internacionalização do capital produtivo e para a constituição e consolidação de grandes corporações multifuncionais e multilocalizadas. As grandes corporações têm gerado redes geográficas, com numerosas unidades, localizadas em diversos lugares distribuídos mundialmente. Essas redes são controladas direta ou indiretamente por poderosas holdings localizadas em importantes centros de gestão do território em nível mundial (CORRÊA, 2016).

As grandes corporações e as empresas multinacionais apropriam-se do território de forma diferenciada, a partir de conteúdos funcionais pré-existentes voltados aos seus interesses, e estabelecendo formas particulares de utilização do espaço (CORRÊA, 2006). O que acaba englobando, conforme Catão, Reolon e Miyazaki (2010, p. 237) uma “discussão sobre as desigualdades, uma vez que as ações e estratégias das grandes corporações, por exemplo, se dão de forma seletiva".

Da mesma forma, Maria Laura Silveira (2002, p. 11) afirma que

as grandes empresas, globais e nacionais, usam o território nacional segundo suas aptidões para determinadas atividades. Assim, criam uma nova divisão territorial do trabalho, em função de seus circuitos de produção e distribuição, que vêm superpor-se a divisões pretéritas do trabalho, moldadas por outras empresas e pelo próprio Estado. A divisão territorial do trabalho interna às empresas termina criando uma expressão territorial do país.

Desse modo, as grandes empresas, ao fazerem suas escolhas locacionais e estabelecerem sua própria divisão territorial do trabalho, não somente alteram a estrutura espacial das cidades onde se instalam, como também têm a capacidade de reafirmar a hierarquia ou a posição que as cidades ocupam na rede urbana.

Esse fenômeno será apresentado neste trabalho, através da análise da divisão territorial do trabalho das cadeias do tabaco e da avicultura, comandadas pelas corporações multilocalizadas, buscando relacionar com a rede urbana da região dos Vales-RS. O tópico a seguir busca apresentar uma breve caracterização da região dos Vales e de sua rede urbana.

\section{A REGIÃO DOS VALES E SUA REDE URBANA}

A região dos Vales apresentava em 2010 uma população total de 745.864 habitantes ${ }^{1}$, sendo que desse total, 68\% reside em área urbana e 32\% em área rural. Apesar da predominância da população urbana na região, dos 59 municípios pertencentes à região, 35 apresentam mais de 50\% da população residindo no meio rural. Há uma maior densidade populacional na sub-região do Vale do

\footnotetext{
${ }^{1}$ Segundo o IBGE (2020a), a população total da região foi estimada em 805.503 habitantes e densidade demográfica de 44,54 hab. $/ \mathrm{km}^{2}$.
} 
Taquari, sendo 67,9 hab./km², em relação a sub-região do Vale do Rio Pardo, que possui densidade de 32,7 hab./ $/ \mathrm{km}^{2}$ (IBGE, 2010).

Quanto à economia regional, a sub-região do Vale do Rio Pardo é a principal área do país na produção de tabaco em folha, sendo responsável pela produção de 159.901 toneladas de tabaco em 2018, o que representou 45\% da produção estadual e 21\% da produção nacional. O Vale do Taquari se destaca principalmente pela produção de carne de frango, sendo que, em 2018, foram criadas na região 43.174 .562 cabeças de galináceos, o que representou $26 \%$ da produção estadual e $3 \%$ da nacional (IBGE, 2018a; 2018b). Além disso, em relação ao total da produção brasileira, em 2018, $67 \%$ da produção de tabaco foi exportada e $28 \%$ do total da produção de carne de frango foi direcionada para exportação em 2018. Na região dos Vales, 350.342 ton. de tabaco em folha e 33 ton. de carne de frango foram exportados em 2018 (COMEX STAT, 2018). Assim, grande parcela da produção, tanto de tabaco, quanto de carne de frango, é voltada para exportação e é realizada sob o comando de empresas multinacionais e multilocalizadas.

Na região dos Vales, as cidades médias de Santa Cruz do Sul e Lajeado se sobressaem pelo maior contingente populacional, respectivamente de 131.365 e 85.033 habitantes estimados em 2020 (IBGE, 2020a), por concentrarem a maior parte dos estabelecimentos industriais, comerciais e de serviços; pelo maior número de empregos formais; e pela presença de sedes e filiais de importantes empresas multinacionais.

Destaca-se em Santa Cruz do Sul o setor de fabricação de produtos do tabaco por empregar, em 2018, em torno de 7 mil trabalhadores temporários e 3 mil trabalhadores permanentes, bem como, a presença de sedes e filiais de multinacionais da indústria tabaqueira, como é o caso da sede brasileira da Universal Leaf Tabacos e da Japan Tobacco International e as filiais da British American Tobacco e da Philip Morris International. Em Lajeado, destaca-se o setor de abate de aves, por empregar 4.982 pessoas em 2018, e pela presença de uma filial da multinacional $B R F$. A presença de sedes e filiais de multinacionais implica no estabelecimento de redes verticais entre Santa Cruz do Sul e Lajeado para com as cidades onde estão localizadas as sedes mundiais destas empresas (RAIS, 2018; CAGED, 2018).

A Figura 1 apresenta a dados da população total estimada por município (IBGE, 2020a), as principais rodovias do sistema rodoviário (DNIT, 2015) e os níveis de hierarquia dos centros urbanos, além das suas regiões de influência, conforme dados da REGIC - 2018 (IBGE, 2020b).

A estrutura viária (Figura 1) contribui e condiciona a dinâmica de relações entre as cidades na rede urbana. Sua estrutura é deficiente quanto à abrangência e à qualidade do sistema viário, havendo maior densidade da malha rodoviária federal e estadual, asfaltada, concentrada na zona central da região. Destacam-se a BR-287 e a BR-386, que atravessam a região dos Vales e conectam a Região 
Metropolitana de Porto Alegre (RMPA), respectivamente, à oeste e ao norte do estado (SEPLAG; DEPLAN, 2015).

A rede urbana da Região dos Vales, de acordo com os dados da REGIC - 2018 (Figura 1), expressa a relação de condição e reflexo da divisão territorial do trabalho que ocorre no espaço regional. Exercendo intermediação entre a metrópole Porto Alegre para com os centros locais, encontram-se, classificadas como Capitais Regionais, os Arranjos Populacionais (AP) $)^{2}$ de Santa Cruz do Sul e de Lajeado. A destacada influência dessas duas cidades médias no espaço regional, se dá através da concentração nelas, de grande parte das empresas industriais e de serviços que integram a divisão territorial do trabalho regional.

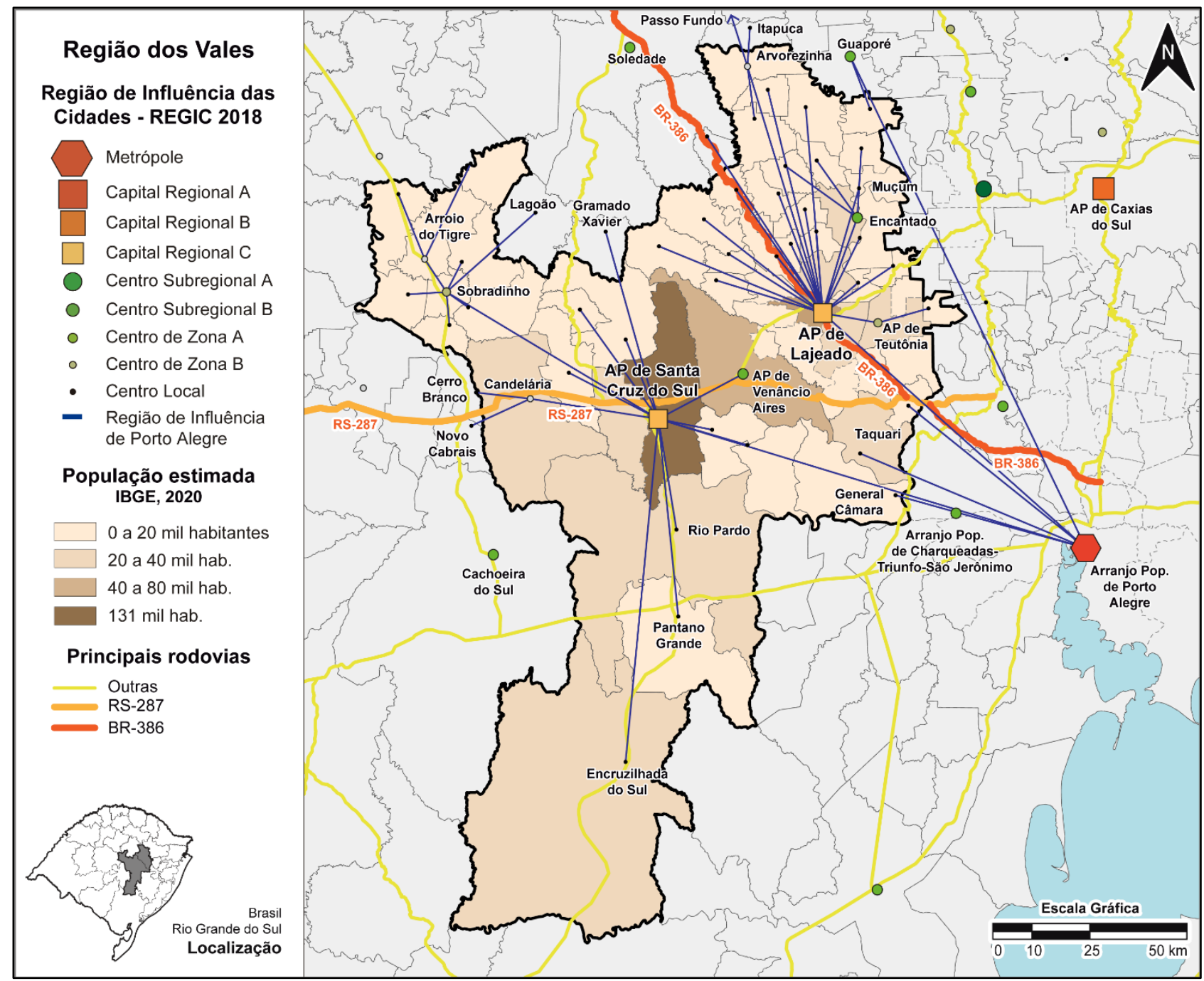

Figura 1 - Sistema viário, população total e rede urbana da região dos Vales-RS

Fonte: Elaborado pelos autores, a partir de IBGE (2020a; 2020b) e DNIT (2015).

2 Os Arranjos Populacionais são constituídos por agrupamentos de Municípios muito integrados por possuírem deslocamentos frequentes de populações para trabalho e estudo, segundo os critérios do estudo Arranjos Populacionais e Concentrações Urbanas do Brasil, publicado pelo IBGE em 2016 (IBGE, 2020b). 
Em um nível intermediário na rede urbana, como Centros sub-regionais, o AP de Venâncio Aires e a cidade de Encantado, e como "Centros de Zona", Sobradinho, Teutônia, Arroio do Tigre e Arvorezinha. Estes municípios se caracterizam por desempenharem papel complementar no sistema urbano regional, pela centralidade urbana que apresentam em relação ao seu entorno imediato, bem como por possuírem algumas e importantes sedes de empresas e indústrias. Os demais municípios ou são classificados como Centros Locais, ou estão inclusos nos Arranjos Populacionais de Santa Cruz do Sul, Venâncio Aires, Lajeado e Teutônia (IBGE, 2020b).

Em relação às regiões de influência existentes na região, representadas por meio de linhas na cor azul, representando as conexões entre municípios, destacam-se o município de Sobradinho, Santa Cruz do Sul, Lajeado, Encantado e Teutônia, que servem como centros de atração para os municípios de seus entornos (Figura 1).

Verifica-se que Lajeado polariza um número maior de municípios em comparação à Santa Cruz do Sul, mesmo que as duas cidades possuam a mesma classificação hierárquica. Isso ocorre não somente por conta de uma relação econômica destes municípios para com Lajeado, mas também em razão do intenso processo de emancipações municipais ocorrido entre os anos de 1981 e 2001, em que 44 municípios foram emancipados de Lajeado, enquanto somente quatro foram emancipados de Santa Cruz do Sul. Esse processo, que ocorreu em todo o Brasil e Rio Grande do Sul, mas de modo ainda mais intenso no Vale do Taquari, resultou numa nova configuração territorial com reflexos na dinâmica de constituição, estrutura e funcionamento da rede urbana regional.

Portanto, a rede urbana regional apresenta estrutura e dinâmica simples de funcionamento dado o expressivo predomínio das pequenas cidades na região e da primazia das cidades de Santa Cruz do Sul e Lajeado. Além disso, o Vale do Taquari apresenta uma estrutura com maior densidade de relações, e um maior número de cidades onde há uma concentração de atividades industriais, de serviços e de comércio, se comparada à do Vale do Rio Pardo - onde as atividades econômicas se concentram em Santa Cruz do Sul e, em menor parte, em Venâncio Aires. O que pode justificar essa diferença entre essas duas sub-regiões é justamente a divisão territorial do trabalho existente em cada uma, já que, conforme Corrêa (2006), a rede urbana reflete e condiciona a divisão territorial do trabalho (Grifo nosso). É o que veremos no tópico a seguir, no contexto das cadeias produtivas do tabaco e da carne de frango e da região dos Vales.

\section{A DIVISÃO TERRITORIAL DO TRABALHO DAS CADEIAS PRODUTIVAS DO TABACO E DA CARNE DE FRANGO NA REGIÃO DOS VALES}

No Vale do Rio Pardo, a economia se estrutura predominantemente através do beneficiamento agroindustrial do tabaco, e no Vale do Taquari, do abate e fabricação de produtos da carne, principalmente de frango. Nesses dois setores predominantes, há, em ambas as sub-regiões, a 
presença hegemônica de subsidiárias de multinacionais e de empresas multilocalizadas regionais. Em um primeiro tópico, apresentaremos a divisão territorial do trabalho da cadeia produtiva do tabaco e, em um segundo, o da carne de frango. Por fim, serão apresentados as semelhanças e particularidades entre as duas cadeias no contexto da região dos Vales

\subsection{A cadeia produtiva do tabaco no Vale do Rio Pardo}

A Figura 2 apresenta um fluxograma explicativo sobre a cadeia de produção do tabaco e dos cigarros. A cadeia é constituída, em síntese, de três elos: a etapa inicial da produção, a de processamento industrial do tabaco e a de fabricação de cigarros. Os insumos necessários são fornecidos por meio de uma cadeia auxiliar e, ao final, parte da produção é destinada ao mercado interno ou à exportação.

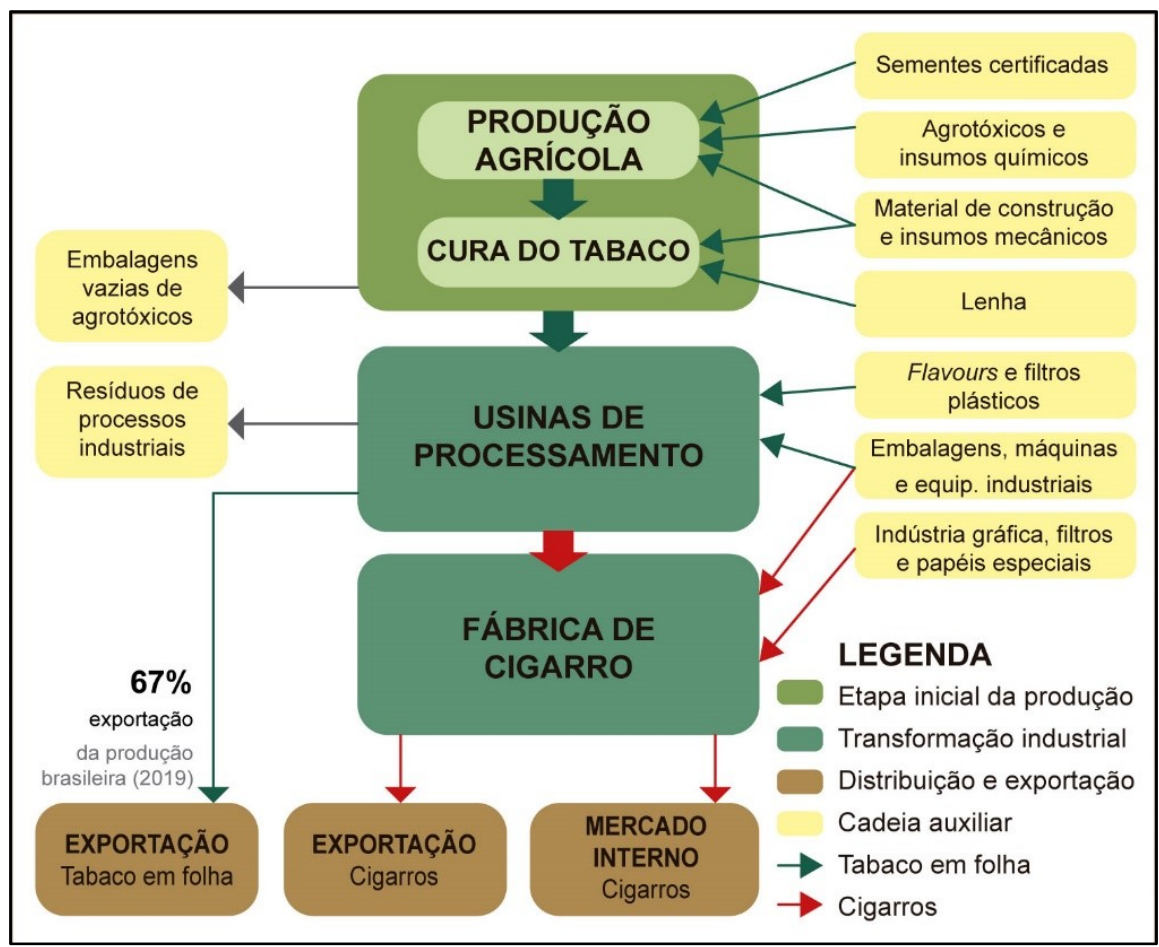

Figura 2 - Cadeia de produção do tabaco e do cigarro - região dos Vales - 2020.

Fonte: Elaborado pelos autores, a partir de Silveira (2007).

A produção do tabaco é realizada com uso intensivo da mão de obra dos agricultores familiares e é regulada pelo sistema integrado de produção. Em torno de 20 mil estabelecimentos agropecuários da agricultura familiar produzem o tabaco na região dos Vales - destes, 87\% estão presentes apenas na região do Vale do Rio Pardo (IBGE, 2017).

Por meio do sistema de integração, a empresa integradora é responsável pelo transporte do fumo dos estabelecimentos rurais até as usinas, bem como, de insumos como sementes certificadas e agrotóxicos ao produtor rural. Nesta etapa, outros insumos são utilizados, como materiais de construção para construção das estufas e lenha para cura do tabaco. Após essa etapa inicial, o tabaco 
curado é transportado em direção às usinas de processamento, onde o produtor rural faz a comercialização de sua produção (SILVEIRA, 2007). Trata-se de um processo de monopolização do território, como definido por Oliveira (1987), no qual ocorre a subjugação da renda terra obtida pelos agricultores familiares da cultura do tabaco por parte do capital agroindustrial multinacional. Capital esse, que em que pese não ser o proprietário das propriedades rurais, através do funcionamento do sistema integrado de produção, monopoliza o uso do território, subordinando os agricultores através da contratualização da comercialização da safra, impondo o pacote tecnológico utilizado na produção, definindo a quantidade e qualidade do tabaco que decide comprar e controlando o preço final do produto entregue pelos agricultores nas usinas de tabaco.

$\mathrm{Na}$ etapa seguinte, o tabaco é processado nas unidades de processamento das empresas tabaqueiras presentes em Santa Cruz do Sul e Venâncio Aires. São utilizados insumos como os flavours, filtros plásticos, embalagens de papel e plásticas, além de maquinários e equipamentos industriais. A maior parte do tabaco processado é destinado à exportação, sendo que $67 \%$ da produção brasileira, em 2018, foi exportada, principalmente para países do continente europeu e asiático (COMEX STAT, 2018). O restante da produção é destinado à fabricação de cigarros, etapa em que são necessários insumos como embalagens, máquinas e equipamentos industriais, filtros e papéis especiais, além do suporte de uma indústria gráfica. Os insumos destinados tanto à etapa inicial da produção nos estabelecimentos rurais, quanto às etapas de processamento do tabaco e de fabricação de cigarros, são adquiridos de empresas localizadas em lugares externos à região dos Vales (SILVEIRA, 2007).

A Figura 3 apresenta a localização das usinas de processamento de tabaco, fábricas de cigarro e as sedes das empresas tabaqueiras multinacionais, a partir de dados da Receita Federal (2020), sites institucionais das empresas e saídas de campo, bem como, mostra a produção de tabaco em folha, por município, conforme IBGE (2018a). 


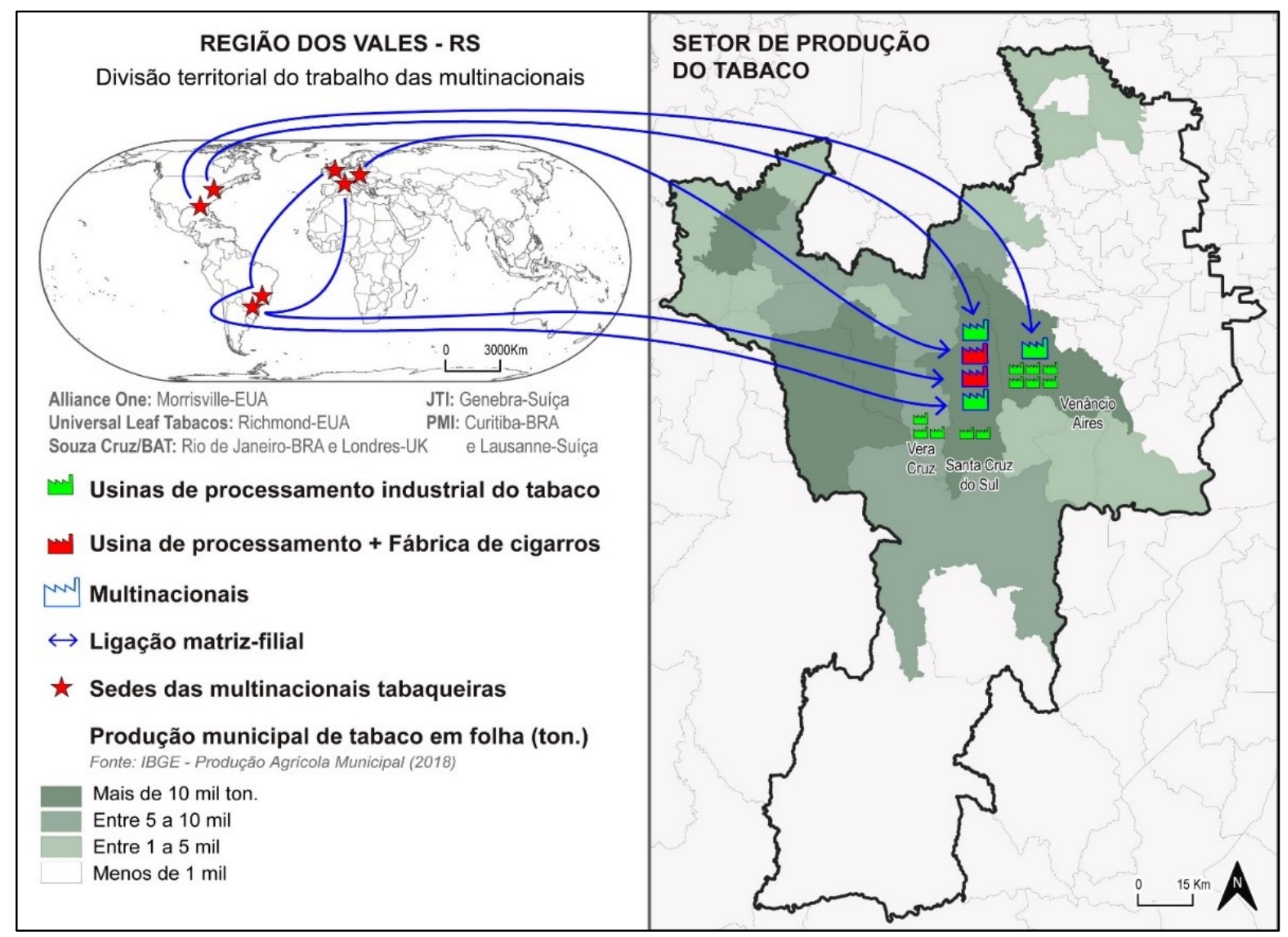

Figura 3 - Divisão territorial do trabalho da cadeia produtiva do tabaco: principais empresas regionais e multinacionais - Região dos Vales - 2020. Fonte: Elaborado pelos autores, a partir de dados da pesquisa.

No âmbito da região dos Vales, os municípios cuja produção de tabaco superou mil toneladas, estão localizados na porção central e norte do Vale do Rio Pardo, além de alguns municípios ao norte do Vale do Taquari. Destacam-se os municípios de Venâncio Aires, Santa Cruz do Sul, Candelária, Vale do Sol e Arroio do Tigre (Figura 3) (IBGE, 2018a).

Em relação à organização espacial das indústrias, observa-se uma concentração das usinas de processamento em Santa Cruz do Sul, Venâncio Aires e, em menor parte, em Vera Cruz. Essas plantas industriais estabelecem fluxos de informação e de capital com suas sedes administrativas em outros países, integrando a região verticalmente à economia globalizada. Assim, graças a sua importância na produção de tabaco em nível nacional, a região do Vale do Rio Pardo é reconhecidamente uma posição estratégica para empresas do ramo. Ela se destaca pela presença, principalmente nos municípios de Santa Cruz do Sul e em Venâncio Aires, de filiais de corporações multinacionais. Destacam-se cinco empresas:

a) a BAT Brasil (anteriormente denominada Souza Cruz Ltda.), cuja matriz está localizada no Rio de Janeiro, e é subsidiária da British American Tobacco - BAT, com sede em Londres, no Reino Unido; 
b) a Philip Morris Brasil Ltda., com matriz localizada em Curitiba, é subsidiária da Philip Morris International, com sede em Lausanne, Suíça;

c) a JTI Processadora de Tabaco do Brasil Ltda., com matriz em Santa Cruz do Sul, subsidiária da Japan Tobacco International - JTI, com sede em Genebra, Suíça;

d) a Alliance One Brasil Exportadora de Tabacos Ltda., com matriz em Venâncio Aires, subsidiária da Alliance One International, com sede em Morrisville, Carolina do Norte, EUA;

e) e a Universal Leaf Tabacos Ltda., com sede em Santa Cruz do Sul, pertencente à Universal Leaf Tabacos, com sede em Richmond, Virgínia, EUA.

Essas cinco empresas possuem como principal atividade o processamento industrial do fumo, sendo que, destas, duas também fabricam cigarros: a JTI e a Philip Morris.

É importante destacar o fato de que na cidade de Santa Cruz do Sul estão localizadas duas sedes nacionais de multinacionais ligadas à produção do tabaco. Isso favorece a posição da cidade na rede urbana, de como que se constitui em um nó estratégico que articula os principais centros produtores e processadores de tabaco, em escala global. Além disso, essa condição amplia a função de gestão privada da cidade não apenas na rede urbana regional, mas também nacional.

A Tabela 1 apresenta o número de empregados formais no setor do processamento industrial do tabaco, por município. A primeira coluna mostra o número de trabalhadores permanentes e, a segunda coluna, a soma das contratações entre janeiro e junho de 2018 - buscando compreender o total de trabalhadores temporários empregados durante o período da safra (CAGED, 2018; RAIS, 2018).

Tabela 1 - Número de trabalhadores do setor de processamento de tabaco - 2018.

\begin{tabular}{ccc}
\hline Municípios & $\begin{array}{c}\text { Número de trabalhadores } \\
\text { permanentes }\end{array}$ & $\begin{array}{c}\text { Número de trabalhadores } \\
\text { temporários (safristas) }\end{array}$ \\
\hline Santa Cruz do Sul & 2.012 & em torno de 5 mil \\
Venâncio Aires & 1.016 & em torno de 4,6 mil \\
Vera Cruz & 125 & em torno de 350 \\
\hline
\end{tabular}

Fonte: RAIS (2018) e CAGED (2018).

Através desses dados, pode-se constatar que em 2018, Santa Cruz do Sul possuía 2.012 trabalhadores permanentes, Venâncio Aires 1.016, Vera Cruz 125 e Rio Pardo 47. Ao longo do ano, as contratações de trabalhadores temporários (os safristas) ocorrem com mais intensidade entre janeiro e maio, diminuindo até agosto. Já as demissões ocorrem entre maio e setembro, quando o período de safra é encerrado. Assim, entre janeiro e junho, foram admitidos em torno de 5 mil trabalhadores temporários em Santa Cruz do Sul, 4,6 mil em Venâncio Aires e 350 em Vera Cruz. Nesse quadro, a região dos Vales possui 10 mil trabalhadores temporários, ou safristas, envolvidos no processamento industrial do tabaco, e 3.153 trabalhadores permanentes. 
Por sua vez, o setor de fabricação de cigarros empregou, em 2018, 1.072 trabalhadores permanentes e, durante o período de safra (de janeiro a junho) em torno de 2,3 mil trabalhadores safristas (CAGED, 2018; RAIS, 2018).

A última etapa da cadeia produtiva do tabaco é a da distribuição e exportação. Em 2019, $67,2 \%$ do tabaco beneficiado industrialmente no Brasil - principalmente na região Sul - foi destinado à exportação (KIST et al., 2019), mas esse valor pode variar para percentuais mais altos, como em 2016, quando a exportação foi de $92 \%$ em relação ao total produzido no ano. A participação do tabaco no total das exportações é bastante significativa, sendo que no Brasil, ela representa $0,8 \%$ em relação ao total exportado pelo país e, no Rio Grande do Sul, representou 7,4\% no total das exportações (SINDITABACO, 2020).

Na região dos Vales, a exportação de tabaco representou 78,4\% do total das exportações em 2018, sendo o produto mais exportado da região. Em Santa Cruz do Sul e Venâncio Aires, respectivamente, $89,75 \%$ e $90 \%$ das exportações são de tabaco processado, sendo que esses são os dois municípios da região que mais exportam produtos (COMEX STAT, 2018).

Também se observa que enquanto o Vale do Rio Pardo exporta majoritariamente tabaco processado, também, em menor parte, exporta máquinas, aparelhos e instrumentos mecânicos; calçados; móveis e mobiliários; sementes e grãos e brinquedos infantis. Já o Vale do Taquari tem uma maior diversidade de produtos exportados, que se destacam em ordem quantitativa de exportação: partes de calçado; erva mate; painéis de MDF; carnes e miudezas de aves; produtos de confeitaria; carnes e miudezas de suínos e farinhas, pó e pellets produzidos a partir dos resíduos do abate de aves e suínos. No tópico seguinte, abordaremos com mais ênfase a exportação da carne de frango no Vale do Taquari.

Com isso, apresentamos a cadeia produtiva do tabaco e a sua divisão territorial do trabalho. Esses dados indicam que a região dos Vales, mas principalmente a região do Vale do Rio Pardo, tem grande importância na cadeia produtiva em âmbito nacional, com integração vertical às sedes das empresas estrangeiras e participação na organização espacial das empresas tabaqueiras em escala mundial. Porém, esses dados também demonstram que os municípios da região têm participado de modo desigual do circuito espacial produtivo e da divisão territorial do trabalho. Enquanto alguns centros participam somente como pontos de passagem da produção do tabaco das suas áreas rurais, Santa Cruz do Sul, Venâncio Aires e, em menor parte, Vera Cruz, participam como centros de comando da produção regional, sede das corporações e das usinas de processamento do tabaco e da fabricação de cigarros. 


\subsection{A cadeia produtiva da carne de frango no Vale do Taquari}

Em relação à cadeia de produção da carne de frango, a Figura 4 apresenta o respectivo fluxograma, que pode ser dividido em cadeia principal - composta pela produção, transformação industrial, distribuição e exportação -, e uma cadeia auxiliar - na qual se destacam, além da produção de insumos, equipamentos e serviços diversos, a produção de ração e a reciclagem animal.

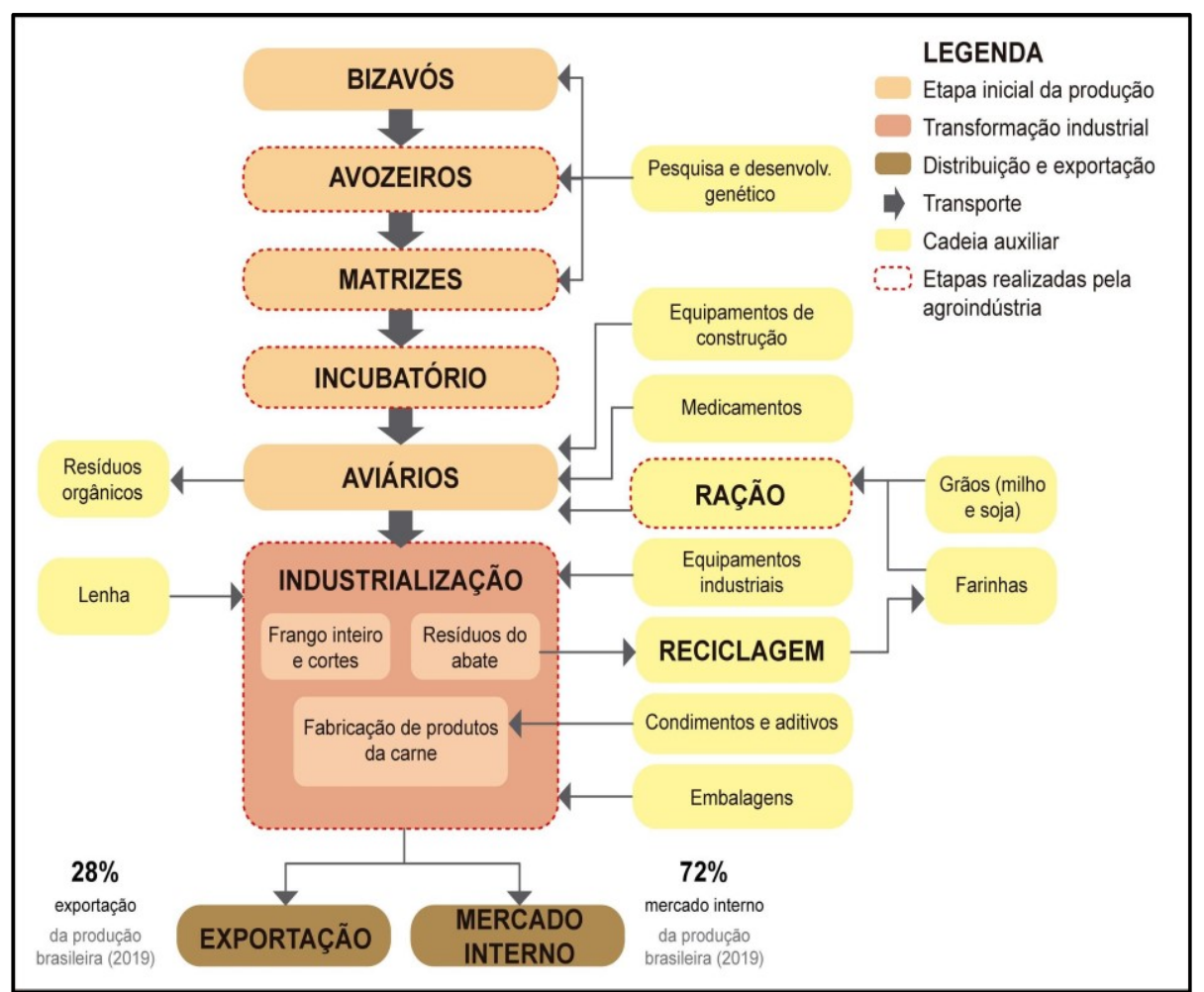

Figura 4 - Cadeia de produção da carne de frango - região dos Vales - 2020.

Fonte: Elaborado pelos autores, a partir de Voila e Triches (2015) e dados da pesquisa.

A etapa inicial da produção envolve a cria do frango e diz respeito a todos os agentes relacionados desde o desenvolvimento da genética dos pintainhos (bisavós); a produção de ovos férteis nas matrizes; nascimento e crescimento dos pintainhos, nos incubatórios; a etapa de engorda, nos aviários, até atingirem a idade do abate. Nessa parte inicial, há o uso de um conjunto de insumos como equipamentos de construção, maquinários, lenha, medicamentos e ração.

A primeira etapa se refere aos bisavós ou, como também pode ser chamada, a da genética e criação de linhagens - geralmente importadas de países como Estados Unidos e Reino Unido. As etapas seguintes, referente aos avozeiros, matrizes e incubatório, são realizadas pela empresa integradora - a mesma que realiza o abate das aves - e se referem ao parque criatório das aves, com a produção de ovos férteis e choca dos ovos no incubatório. Por meio do sistema de integração avícola, a coordenação central ou controle de toda a cadeia fica a cargo da agroindústria.

A próxima etapa é realizada nos avozeiros, granjas nas quais as aves poedeiras avós, originadas a partir da importação de ovos das linhagens, são cruzadas para produzir as matrizes. Por 
sua vez, os matrizeiros são as granjas nas quais as aves matrizes vão gerar os ovos férteis que serão posteriormente encaminhados para o incubatório. Este último refere-se ao local onde os ovos serão chocados no período de aproximadamente 21 dias, dando origem aos pintainhos que são levados para engorda nos aviários.

Após o nascimento dos pintainhos nos incubatórios, eles são entregues aos aviários, onde é realizada a etapa de engorda das aves. Essa etapa é terceirizada pelas empresas abatedoras, que contratam produtores rurais através do sistema de integração vertical. No caso da região dos Vales, essa etapa é realizada em pequenos estabelecimentos agropecuários vinculados à agricultura familiar. Por meio do sistema de integração, a empresa fornece aos produtores medicamentos e ração - esta, por sua vez, produzida pela própria empresa nas suas respectivas fábricas de rações.

A etapa de engorda das aves envolve 1.480 propriedades com mais de 200 cabeças de frangos, 93\% delas concentradas no Vale do Taquari. Desse total, 1.250 estabelecimentos possuem mais de 10.001 cabeças de frango. A maior parte dessas propriedades estão ligadas à agricultura familiar (IBGE, 2017).

Outros segmentos estão envolvidos na etapa de engorda do frango, identificados como parte da cadeia auxiliar (Figura 4). Destacam-se os segmentos da indústria de produtos farmacêuticos, que fornecem vacinas e antibióticos utilizados no tratamento das aves; a indústria de produtos químicos, responsável pela produção de produtos químicos, para limpeza e manutenção dos aviários; e a produção e o fornecimento de equipamentos de construção para os aviários e de máquinas para o trabalho nas granjas (como vacinadoras e debicadores). Com exceção da indústria de produtos farmacêuticos, cujos fornecedores estão em outros países, os fornecedores de produtos de limpeza e materiais de construção estão em municípios próximos da região dos Vales.

Para a produção de ração, são necessários alguns componentes. O primeiro e principal, são os grãos - em geral, milho e soja. Uma vez que a ração é parte fundamental para a alimentação das aves e responsável por uma parcela considerável dos custos de produção, há uma necessidade das indústrias da carne de permanecerem próximas às áreas de produção de grãos. Por conta disso, a indústria avícola brasileira possui a vantagem do Brasil ser um grande produtor de grãos como milho e soja, o que auxilia a diminuir a dependência do mercado externo, torna a oferta de insumos mais estável e reduz os custos de transporte (TRICHES; SIMAN; CALDART, 2004).

A partir da produção de milho e soja, do Premix e das farinhas de carnes, a ração é produzida pela agroindústria, como uma de suas responsabilidades estabelecidas no contrato do sistema de integração. Na região dos Vales, destacam-se a fábrica de rações da BRF, da Minuano e a da Cooperativa Dália Alimentos, em Arroio do Meio, e da Cooperativa Languiru, em Estrela.

Ao final da etapa de produção, quando o frango atinge idade e peso de abate, o produtor tem a obrigação de comercializar sua produção junto à empresa integradora que fará o abate do animal, 
conforme o contrato estabelecido no sistema de integração. Assim, na sequência, após a engorda das aves, elas são transportadas até os abatedouros. O frango pode ser comercializado em cortes ou inteiro, ou ainda, ser destinado à fabricação de produtos da carne como embutidos. Nessa etapa são necessários insumos como equipamentos industriais, condimentos e aditivos e embalagens plásticas e de papel.

Na etapa de transformação industrial estão envolvidos insumos, equipamentos e maquinários industriais; condimentos e aditivos, tais como sabores, temperos e corantes, para elaboração de embutidos e outras preparações; condimentos como massas alimentícias, leite e laticínios para fabricação de outros produtos, como pratos prontos, comidas congeladas e lanches com carne; lenha de eucalipto para aquecimento das caldeiras; e embalagens de plástico e papelão para acondicionamento dos produtos a serem distribuídos, comercializados e exportados. Por fim, outros insumos utilizados são os maquinários e equipamentos industriais e embalagens de plástico e de papelão, para acondicionamento dos produtos (Figura 4). Observa-se que o fornecimento desses produtos ocorre a partir de municípios externos à região dos Vales, em municípios do Estado do Paraná e São Paulo. Há algumas exceções, como é o caso da empresa Bremil S/A Indústria de Produtos Alimentícios, que produz condimentos e aditivos utilizados para elaboração de produtos cárneos, embutidos e outras preparações e está localizada em Arroio do Meio, no Vale do Taquari.

Ainda, o abate das aves gera resíduos como sangue, vísceras, penas e ossos, que são destinados à etapa de reciclagem animal, em empresas específicas do ramo, onde são produzidos farinhas, óleos e gorduras a partir desses resíduos. A maior parte das farinhas geradas, são destinadas à produção de ração de animais de produção e de animais domésticos. Na região dos Vales, destacamse duas empresas, localizadas em Cruzeiro do Sul, que fazem o recebimento e o tratamento não somente dos resíduos do abate de aves, mas também de suínos e bovinos. Também há a presença de três empresas de grande porte, localizadas em Arroio do Meio, Encantado e Imigrante, de fabricação de sabões e detergentes sintéticos, que podem utilizar esses resíduos do abate como uma de suas matérias primas.

Por último, em relação à etapa de distribuição e exportação, verifica-se que no caso brasileiro, a maior parte da produção é destinada ao consumo no mercado interno. Em 2018, 72\% da produção de carne de aves foi destinada ao mercado interno e $28 \%$ destinada à exportação principalmente para países do Oriente Médio, da Ásia e África (COMEX STAT, 2018).

A Figura 5 apresenta, inicialmente, o total dos rebanhos de galináceos por município, evidenciando que, no âmbito da região dos Vales, os rebanhos estão concentrados em todo o Vale do Taquari, mas principalmente na sua porção central. Destacam-se os municípios de Nova Bréscia, Westfália, Estrela e Encantado, com rebanhos de galináceos superiores a 2 milhões de cabeças (IBGE, 2018b). 
Além disso, a Figura 5 apresenta a localização das plantas industriais de abate de aves, abate de suínos, fabricação de produtos da carne e fábrica de rações, bem como, as plantas das empresas multinacionais - notadamente, a BRF e JBS - na região dos Vales, a partir de dados da Receita Federal (2020), do MAPA (2020), sites institucionais das empresas e pesquisa em campo. A Figura 5 ainda indica as ligações entre as matrizes e filiais das empresas.

A região está verticalmente integrada à economia globalizada pela presença de filiais das duas maiores empresas brasileiras de produção de carne no Brasil: a BRF S.A., empresa resultante da fusão da Sadia e Perdigão, e a Seara Alimentos Ltda., de propriedade da JBS S.A. Ambas são de origem brasileira e, através de apoio do Banco Nacional de Desenvolvimento Econômico (BNDES), entre 2007 e 2013, expandiram suas operações em diversos países, tornando-se empresas multinacionais (SHARMA, 2017).

A BRF, cuja sede está localizada em Itajaí, Santa Catarina, possui na região dos Vales uma planta industrial de abate de aves, em Lajeado, e uma fábrica de rações, em Arroio do Meio. Já a Seara Alimentos/JBS, cuja matriz está localizada na cidade de São Paulo, possui unidades de fabricação de produtos da carne de aves e suínos (como alimentos embutidos), em Bom Retiro do Sul e Roca Sales, bem como, em Santa Cruz do Sul - onde está localizada a Excelsior Alimentos S.A., subsidiária da Seara/JBS.

Além destas, destacam-se outras empresas multilocalizadas com origem e forte presença na região. A Companhia Minuano de Alimentos, com matriz e unidade de abate de aves em Lajeado, e fábrica de rações e fábrica de embutidos em Arroio do Meio. As operações dessa empresa são voltadas, em maior parte, para a prestação de serviços - mais especificamente, o abate de aves - para a BRF.

A região dos Vales também possui a presença das cooperativas Dália e Languiru, que atuam nos setores de carne de aves e suínos e laticínios. A Cooperativa Dália possui sua matriz em Encantado, mas as unidades produtivas do seu complexo avícola - em funcionamento desde janeiro de 2020 - estão localizadas em Arroio do Meio. Já a Cooperativa Languiru possui sua matriz em Teutônia, unidade de abate de aves em Westfália e fábrica de rações em Estrela ${ }^{3}$. Por fim, a região também conta com frigoríficos de menor porte, como a Granja Bom Frango, em Venâncio Aires, e o Frigorífico Rio Pardinho, com sede em Santa Cruz do Sul.

A Tabela 2 informa o número de trabalhadores nos setores de abate de aves e fabricação de produtos da carne, de acordo com a RAIS (2018). Há pouca variação entre os admitidos e demitidos

\footnotetext{
${ }^{3}$ Ressaltamos que, apesar de inicialmente nos propormos a analisar a atuação das empresas multinacionais na região dos Vales, foi necessário, no caso do Vale do Taquari e da produção da carne de frango, incluir as empresas e as cooperativas regionais como parte da análise, ou seja, a empresa Minuano e as cooperativas Dália e Languiru. Os dados coletados nesta pesquisa acabaram demonstrando que elas representam parte importante da cadeia produtiva, no contexto regional, seja pelo significativo número de trabalhadores industriais empregados, seja pelo alto montante exportado, ou ainda pela quantidade de unidades dispostas e presentes na região.
} 
ao longo do ano, em comparação ao setor de processamento do tabaco e de fabricação de cigarros. Enquanto a cadeia do tabaco é organizada de acordo com o período da safra, a produção de carne é feita de forma constante ao longo do ano, sendo que todas as pausas devem ser programadas, como feriados e finais de semana.

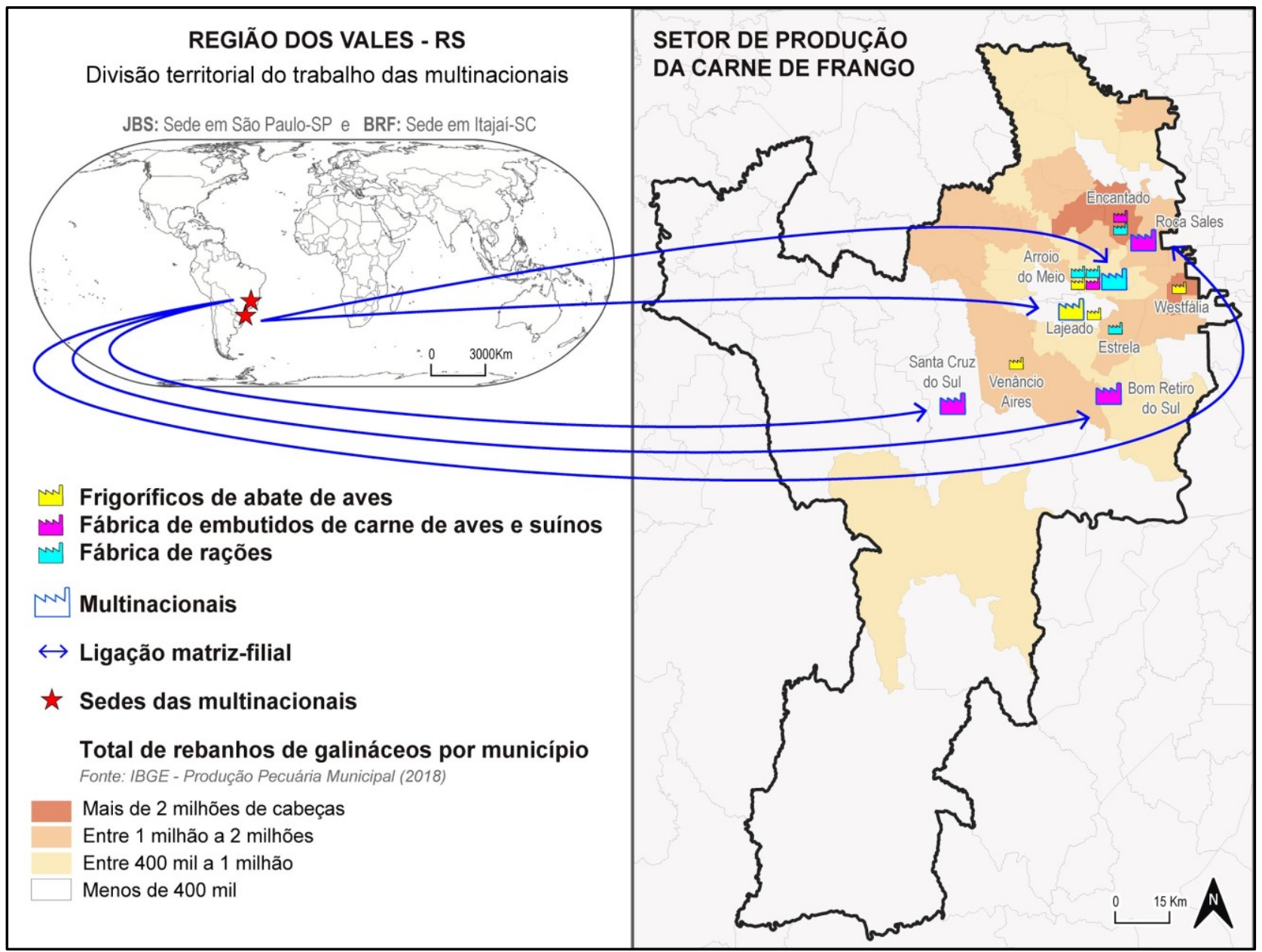

Figura 5 - Divisão territorial do trabalho da cadeia produtiva da carne de frango: principais empresas regionais e multinacionais - Região dos Vales - 2020. Fonte: Elaborado pelos autores, a partir de dados da pesquisa.

Destacam-se os municípios de: Lajeado, onde estão presentes os dois maiores frigoríficos da região dos Vales: a BRF S.A., responsável pelo abate de aves e suínos, com 2.904 trabalhadores, e a Minuano, frigorífico de abate de aves, com 2.011 trabalhadores; Westfália, onde está localizado o frigorífico de abate de aves da Cooperativa Languiru Ltda., com 888 trabalhadores; Santa Cruz do Sul, onde está a fábrica de produtos da carne Excelsior Alimentos S.A., cuja produção se concentra na fabricação de embutidos de carne de suínos e de aves, laticínios e pratos prontos, e emprega 625 trabalhadores; Roca Sales e Bom Retiro do Sul, onde estão localizadas plantas da Seara Alimentos Ltda., responsáveis pela fabricação de produtos da carne de frangos e suínos, com respectivamente 479 e 463 trabalhadores; Venâncio Aires, onde está localizada a Granja Avícola Bom Frango Ltda., responsável pelo abate de aves, especializada em cortes resfriados e desossados, com 180 
trabalhadores empregados; Estrela, onde está localizada a fábrica de rações da Cooperativa Languiru, com 179 trabalhadores; e Teutônia, onde está a sede da Cooperativa Languiru, além do incubatório de frangos, e matrizes de suínos e frangos, somando 180 trabalhadores da empresa nesse município.

Tabela 2 - Número de trabalhadores nos setores de abate de aves, fabricação de produtos da carne e fabricação de ração -2018 .

\begin{tabular}{cccc}
\hline Municípios & Abate de aves & Fabricação de produtos da carne & Fabricação de ração \\
\hline Lajeado & 4.982 & & \\
Westfália & 888 & 625 & \\
Santa Cruz do Sul & & 483 & \\
Roca Sales & & 463 & 140 \\
Bom Retiro do Sul & & 306 & \\
Arroio do Meio & & 147 & 179 \\
Encantado & \multirow{2}{*}{180} & & \\
Venâncio Aires & & & \\
Estrela & & & \\
\hline
\end{tabular}

Fonte: RAIS (2018).

Por último, se destaca o município de Arroio do Meio, onde estão localizadas a fábrica de rações (101 trabalhadores) e uma granja de produção de frangos da BRF S.A.; a fábrica de rações (39 trabalhadores) e uma planta industrial responsável pela fabricação de produtos da carne (306 trabalhadores), da Companhia Minuano de Alimentos. Ainda estão presentes as já citadas empresas Bremil e Girando Sol, que compõem a cadeia auxiliar da produção de carne de frango.

De acordo com Silva (2020), Arroio do Meio também abriga o complexo avícola e lácteo da Cooperativa Dália de Alimentos Ltda, composto por duas fábricas de laticínios ${ }^{4}$ (uma localizada no distrito de Palmas, com 192 funcionários, e outra no bairro Aimoré, com 85 empregados), uma fábrica de rações, uma fábrica de farinhas de origem animal e um frigorífico de abate de aves (com 320 funcionários), estas últimas inauguradas em dezembro de 2019 e em funcionamento desde o começo de 2020.

Os demais municípios da região participam da cadeia produtiva através da criação das aves em matrizeiros e incubatórios, sob responsabilidade da empresa integradora; ou da engorda do frango de corte, em aviários, sob responsabilidade de produtores rurais em pequenos estabelecimentos agropecuários ligados à agricultura familiar.

\footnotetext{
${ }^{4}$ Importante destacar que o setor de produção da carne de frango da região e, tão logo, as empresas selecionadas, estão fortemente integrados aos setores de produção suínos (exceto a empresa Minuano, uma vez que sua produção é exclusivamente de carne de frango) e produção de leite e laticínios (como é o caso das Cooperativas Dália e Languiru).
} 


\section{SEMELHANÇAS E PARTICULARIDADES ENTRE AS CADEIAS PRODUTIVAS E A DIVISÃO TERRITORIAL DO TRABALHO DO TABACO E DA CARNE DE FRANGO NA REGIÃO DOS VALES}

Por fim, neste último tópico apresentamos as semelhanças e particularidades entre as cadeias produtivas e a divisão territorial do trabalho do tabaco e da carne de frango, descritos inicialmente no Quadro 1.

Quadro 1: Semelhanças e particularidades entre as cadeias produtivas e a divisão territorial do trabalho do tabaco e da carne de frango na região dos Vales.

\begin{tabular}{|c|c|c|}
\hline Item & Setor do tabaco & Setor da carne de frango \\
\hline $\begin{array}{l}\text { Temporalidade da } \\
\text { produção }\end{array}$ & $\begin{array}{l}\text { Produção organizada de acordo com a } \\
\text { safra anual. } \\
\text { Cultivo e colheita: } 2^{\circ} \text { semestre do ano } \\
\text { Processamento industrial: } 1^{\circ} \text { semestre } \\
\text { do ano }\end{array}$ & Produção constante ao longo do ano. \\
\hline \multirow{3}{*}{ Produção rural } & $\begin{array}{l}\text { Na região dos Vales }(2018) \text { : } \\
\text { A produção de tabaco corresponde a } \\
45 \% \text { da produção estadual. }\end{array}$ & $\begin{array}{l}\text { Na região dos Vales (2018): } \\
\text { Os rebanhos de galináceos no Vale do Taquari } \\
\text { correspondem a } 24 \% \text { do total do RS. }\end{array}$ \\
\hline & $\begin{array}{l}18.766 \text { estabelecimentos agropecuários } \\
\text { produtores de tabaco. }\end{array}$ & $\begin{array}{l}\text { Em torno de } 1.408 \text { estabelecimentos } \\
\text { agropecuários produtores de frango de corte. }\end{array}$ \\
\hline & 159.901 toneladas produzidas. & 43.174.562 cabeças de galináceos produzidas. \\
\hline \multirow[b]{2}{*}{$\begin{array}{l}\text { Comercialização da } \\
\text { produção rural e valor } \\
\text { pago ao produtor }\end{array}$} & Compra garantida. & Compra garantida. \\
\hline & $\begin{array}{l}\text { Valor pago varia conforme a qualidade } \\
\text { do tabaco e a demanda mundial pelo } \\
\text { produto. }\end{array}$ & $\begin{array}{l}\text { Valor unitário por cabeça, somado a uma taxa } \\
\text { adicional conforme eficiência da produção } \\
\text { (mais carne produzida para uma menor } \\
\text { quantidade de ração consumida). }\end{array}$ \\
\hline \multirow[b]{2}{*}{ Sistema de integração } & Apresenta sistema de integração. & Apresenta sistema de integração. \\
\hline & & $\begin{array}{l}\text { As aves são de propriedade da empresa. Por } \\
\text { isso, ela assume um maior número de etapas da } \\
\text { cadeia produtiva. }\end{array}$ \\
\hline $\begin{array}{c}\text { Distribuição das } \\
\text { plantas industriais das } \\
\text { empresas } \\
\end{array}$ & $\begin{array}{l}\text { Concentradas em Santa Cruz do Sul e } \\
\text { Venâncio Aires }\end{array}$ & $\begin{array}{l}\text { Distribuídas em Lajeado, Encantado, Teutônia, } \\
\text { Arroio do Meio, Estrela, Westfália, Santa Cruz } \\
\text { do Sul, Bom Retiro do Sul e Roca Sales. }\end{array}$ \\
\hline $\begin{array}{l}\text { Principais empresas } \\
\text { presentes na região }\end{array}$ & Cinco multinacionais & $\begin{array}{l}\text { Duas multinacionais, uma empresa regional e } \\
\text { duas cooperativas }\end{array}$ \\
\hline \multirow{2}{*}{$\begin{array}{l}\text { Trabalhadores } \\
\text { industriais }\end{array}$} & $\begin{array}{l}4.272 \text { trabalhadores industriais efetivos } \\
\text { (RAIS, 2018). }\end{array}$ & $\begin{array}{l}8.278 \text { trabalhadores industriais efetivos (RAIS, } \\
2018 \text { ). }\end{array}$ \\
\hline & $\begin{array}{l}\text { Aprox. } 12.250 \text { trabalhadores industriais } \\
\text { safristas (RAIS, 2018; CAGED, 2018). }\end{array}$ & \\
\hline Exportação & $\begin{array}{l}\text { 67\% da produção brasileira exportada } \\
\text { (COMEX STAT, 2018) }\end{array}$ & $\begin{array}{l}28 \% \text { da produção brasileira exportada (COMEX } \\
\text { STAT, 2018) }\end{array}$ \\
\hline
\end{tabular}

Fonte: Elaborado pelos autores, a partir de dados da pesquisa.

Uma das principais diferenças entre as duas cadeias é a temporalidade da produção. No caso do tabaco, a produção é organizada de acordo com a safra. De modo geral, enquanto no segundo semestre do ano ocorre o cultivo e a colheita do tabaco, no primeiro semestre ocorre o processamento industrial. Já a produção de carne de frango é estável e constante ao longo do ano, sendo que todas as pausas na linha de produção e de abate devem ser programadas - como em feriados -, já que 
envolvem um produto altamente perecível e a criação controlada do frango.

Em relação à produção rural, observamos que no Vale do Rio Pardo predomina a produção de tabaco e, no Vale do Taquari, a produção de frango de corte. A exceção é o município de Venâncio Aires que, além de possuir uma expressiva participação na cadeia produtiva do tabaco, também possui participação na produção de frango, haja vista a proximidade espacial entre as duas regiões. Além disso, observa-se na região dos Vales um maior número de propriedades rurais vinculadas à produção do tabaco do que vinculadas à produção de frango de corte.

Em relação à comercialização da produção rural, os produtores de ambos os setores produtivos possuem a compra garantida da produção rural - o que é firmado pelo contrato estabelecido no âmbito do sistema de integração. O valor pago ao produtor, na cadeia do tabaco, é baseado, em tese, em uma complexa classificação que varia de acordo com a qualidade do tabaco produzido. Na prática, as empresas decidem, de acordo com seus interesses e com a demanda global do produto, o grau de rigor a ser adotado na classificação do tabaco. Já o valor pago aos avicultores pela produção do frango é estabelecido previamente em contrato, havendo ainda uma taxa adicional correspondente à eficiência produzida. Porém, em ambos os casos, há uma subordinação dos produtores para com as empresas.

Uma semelhança relevante entre os dois setores é em relação ao sistema de integração, além do meio de controle e coordenação dos setores produtivos pelas empresas, por meio de um processo de transmissão de informações, estímulos e controles para orientar o movimento dos agentes de forma consistente com objetivos estratégicos. As empresas desses setores estabelecem um conjunto de ações, no bojo dos seus respectivos setores produtivos e através do sistema de integração, coordenando a obtenção de todos os suprimentos de que precisam para realizar a produção. Dessa forma, tanto as indústrias tabaqueiras, quanto as indústrias da produção de carne exercem controle sobre o funcionamento da cadeia como um todo. No entanto, comparativamente, na cadeia da carne de frango a empresa assume uma série de riscos e de atividades - como a criação das aves, produção de ração, além do abate das aves. Ou seja, há uma complexa e interligada infraestrutura física, que se distribui no território regional.

Em relação ao tabaco, a distribuição das plantas industriais das empresas no território regional é concentrada no Vale do Rio Pardo, sendo que as empresas tabaqueiras estão localizadas em Santa Cruz do Sul e, em menor quantidade, em Venâncio Aires. Já no Vale do Taquari, há uma maior quantidade de infraestrutura e de plantas industriais sob responsabilidade da empresa produtora de carne, com uma - comparativamente - maior distribuição espacial na região.

No caso da cadeia produtiva da carne de frango, um fator que influencia nessa maior distribuição das plantas industriais entre diversos municípios é justamente o maior controle que as empresas têm sobre a cadeia produtiva. Em função das aves serem de propriedade das empresas, as 
próprias empresas tornam-se responsáveis pelas granjas de avós (avozeiro), criação dos ovos férteis (matrizeiros), incubação dos ovos (incubatório), além de serem responsáveis pela fabricação da ração (fábrica de rações) e, claro, pelo abate das aves (frigorífico abatedouro). Cada uma dessas etapas pode ser realizada em um estabelecimento diferente, conforme seja mais vantajoso para a empresa, visando a reprodução do capital.

Quanto às principais empresas presentes na região, foram identificadas cinco empresas tabaqueiras multinacionais na região dos Vales. Esse montante é maior do que o de empresas multinacionais do setor da carne de frango na região, que apresentam duas multinacionais instaladas no espaço regional, notadamente as duas maiores presentes no Brasil - a JBS e a BRF. Ainda devemos considerar a importante atuação da Companhia Minuano de Alimentos, dado o alto número de trabalhadores industriais envolvidos. Há também a presença das duas cooperativas Dália e Languiru, que cada vez mais têm se inserido no setor da produção de frango de corte, de modo a competir com as maiores empresas do mercado. Com isso, nota-se que ambas as regiões estão integradas a redes de nível nacional e mundial, graças à implantação das sedes dessas empresas multinacionais no seu território.

Cabe destacar a importância do Vale do Rio Pardo no complexo agroindustrial do tabaco, tanto em âmbito nacional quanto global. É desde essa região que se realizam as ações dos principais agentes sociais e econômicos do setor. Na região estão sediadas as principais representações políticas do setor, como a AFUBRA (Associação dos Fumicultores do Brasil), o FENTIFUMO (Federação Nacional dos Trabalhadores nas Indústrias do Fumo e Afins) e o SINDITABACO (Sindicato Interestadual da Indústria do Tabaco), que representam, respectivamente, produtores rurais, trabalhadores industriais e empresários do setor fumageiro, em nível nacional. As ações desses agentes constituem fluxos de informações, de normas, de regulações e de interesses corporativos que circulam desde a região em direção às áreas de produção de tabaco.

Em relação aos trabalhadores industriais de cada uma das cadeias produtivas, vale ressaltar uma importante distinção. Os frigoríficos de abate de aves possuem trabalhadores efetivos que, apesar da grande rotatividade de empregados, têm a garantia de um emprego estável. Já na cadeia do tabaco, a maior parte dos trabalhadores são temporários, empregados somente durante o período de safra, o que ocasiona, no Vale do Rio Pardo, no deslocamento dessa força de trabalho para realização de atividades informais fora do período de safra.

Em relação à exportação, observa-se que a maior parte da produção de tabaco é exportada, enquanto a maior parte da produção de carne de frango vai para o mercado interno. Enquanto os frigoríficos de abate de aves exportam $28 \%$ da produção brasileira, sendo o resto destinado ao consumo no mercado interno, a quantidade de tabaco exportada na região é de $67 \%$, sendo o restante destinado à produção de cigarros - que será, majoritariamente, consumido no mercado interno 
(ABPA, 2018; SINDITABACO, 2020).

\section{CONSIDERAÇÕES FINAIS}

Os dados referentes à rede urbana, de acordo com a REGIC - 2018, do IBGE, mostram que ambas as regiões apresentam uma estrutura e dinâmica simples de funcionamento, dado o expressivo predomínio das pequenas cidades na região e da primazia das cidades de Santa Cruz do Sul e Lajeado. Porém, observa-se que o segmento da rede urbana da sub-região do Vale do Taquari apresenta um maior número de subcentros para além de Lajeado, como Estrela, Encantado, Arroio do Meio e Teutônia, onde há uma concentração de atividades industriais, de serviços e comércio. Diferentemente, no segmento da rede urbana do Vale do Rio Pardo, há uma concentração das atividades em Santa Cruz do Sul e, em menor parte, em Venâncio Aires. Em síntese, o que se observa é que o Vale do Taquari apresenta estrutura com maior densidade de fluxos do que a do Vale do Rio Pardo. O que pode justificar essa diferença é justamente a divisão territorial do trabalho existente em cada uma das sub-regiões.

Os resultados mostram que as empresas existentes na sub região do Vale do Taquari, referentes ao setor de produção da carne de frango - notadamente o setor produtivo predominante -, possuem abrangência regional ou nacional e possuem suas atividades distribuídas em um ou mais municípios da região, como Lajeado, Teutônia, Encantado, Bom Retiro do Sul e Roca Sales. Diferentemente, na sub-região do Vale do Rio Pardo, as atividades referentes ao setor de produção do tabaco são realizadas por uma hegemonia oligopolista das corporações multinacionais que operam no mercado internacional de tabaco. Essas empresas se concentram principalmente na cidade de Santa Cruz do Sul, classificada de acordo com a REGIC - 2018 como capital regional, e em menor parte, em Venâncio Aires, classificada como centro sub-regional.

No bojo do Vale do Rio Pardo, e por meio da cadeia produtiva do tabaco, perpassam fluxos horizontais - relacionados à produção de fumo em meio rural e ao deslocamento da produção para os centros regionais onde estão localizadas as usinas de processamento do fumo. Mas também existem fluxos verticais - ou seja, integrando centros de comando que não necessariamente ocorrem no próprio local, e sim, por agentes de lugares distantes e de outros países.

É preciso considerar que o papel hegemônico que essas corporações multinacionais desempenham, através das suas sedes e filiais localizadas nos municípios da região dos Vales, exercem influência na dinâmica dos fluxos de capital, informação, pessoas e produtos, sem a necessidade de tais fluxos passarem pelas capitais estaduais, centros nacionais globais, como RJ e SP, para então se encaminharem ao exterior, ou vice-versa. 
Assim, a divisão territorial do trabalho no território reflete as estratégias espaciais e produtivas postas em prática pelas corporações multinacionais das respectivas cadeias. As ações dessas corporações, contribuem para conformação de uma rede urbana regional cuja racionalidade de funcionamento revela uma forma organizacional verticalizada, hierarquicamente estruturada e regulada externamente. Assim, os fluxos que interceptam o território regional evidenciam que estamos diante de uma região verticalmente integrada à economia globalizada por meio das ações e regulações operadas pelas multinacionais presentes na região, no mercado mundial. Por meio dessa integração vertical, a dinâmica e a rede urbana regional, as ações das empresas e os trabalhadores ficam suscetíveis às variações de preço ocorridas no mercado global e às demandas exigidas por diferentes países.

Observa-se que a distribuição das empresas no território regional é concentrada, no caso das indústrias tabaqueiras no Vale do Rio Pardo, em Santa Cruz do Sul e em Venâncio Aires. Já no Vale do Taquari, há, comparativamente, uma maior distribuição das unidades produtivas nos municípios da região. Há unidades de abate de aves em Westfália e Lajeado, unidades de embutidos em Arroio do Meio, Bom Retiro do Sul, Roca Sales e Santa Cruz do Sul, além das fábricas de rações, incubatórios e matrizes - estabelecimentos gerenciados pelas indústrias avícolas - que se distribuem por uma série de municípios de médio e pequeno porte na região.

Dessa forma, no contexto da região em estudo, os estabelecimentos de produção de carne de frango são mais descentralizados em comparação aos relacionados à produção de tabaco, bem como, a rede urbana e divisão territorial do trabalho da sub-região do Vale do Taquari apresenta maior complexidade funcional, se comparado a da sub-região do Vale do Rio Pardo. Essa constatação reitera a fundamentação teórica vista anteriormente de que a rede urbana é simultaneamente um reflexo da divisão territorial do trabalho e uma condição para o seu funcionamento. Igualmente, confirma-se na análise da região em estudo, que a complexidade da forma espacial da rede urbana e da sua estrutura funcional são correlatas.

\section{REFERÊNCIAS}

ASSOCIAÇÃO BRASILEIRA DE PROTEÍNA ANIMAL (ABPA). Relatório Anual ABPA 2018. São Paulo: ABPA, 2018. Disponível em: <http://abpa-br.com.br/storage/files/relatorio-anual2018.pdf $>$. Acesso em: 6 jan. 2020.

ARROYO, M.; DA CRUZ, R. C. A. Território e Circulação - A dinâmica contraditória da globalização. São Paulo: Anna Blume, 2015. 364p.

CADASTRO GERAL DE EMPREGADOS E DESEMPREGADOS (CAGED). Número de empregados admitidos e demitidos por mês por setor CNAE 2.0. 2018. Disponível em: http://bi.mte.gov.br/bgcaged/caged_rais_vinculo_id/login.php. Acesso em: 24 set. 2020. 
CATÃO, R. C.; REOLON, C. A.; MIYAZAKI, V. K. Interações Espaciais: Uma Reflexão Temática. Caminhos de Geografia, Uberlândia, v. 11, n. 35, p. 231-239, 2010.

COMEX STAT. Exportação e Importação Municípios. 2018. Disponível em: http://comexstat. mdic.gov.br/pt/município. Acesso em: 24 set. 2020.

CORREAA, R. L. Estudos sobre a Rede Urbana. Rio de Janeiro: Bertrand Brasil, 2006. 332p.

CORREAA, R. L. Processos, formas e interações espaciais. Revista Brasileira de Geografia, Rio de Janeiro, v. 61, n. 1, p. 127-134, 2016.

DEPARTAMENTO NACIONAL DE INFRAESTRUTURA DE TRANSPORTES (DNIT). Rodovias federais. Disponível em: http://servicos.dnit.gov.br/vgeo/. Acesso em: 19 mar. 2020.

FRESCA, T. M. Rede urbana e divisão territorial do trabalho. Geografia, Londrina, v. 19, n. 2, p. 115-126, 2010.

KIST, B. B.; CARVALHO, C.; BELING, R. R.; TREICHEL, M.; GARCIA, P. Anuário Brasileiro do Tabaco 2019. Santa Cruz do Sul: Editora Gazeta Santa Cruz, 2019. 132p.

INSTITUTO BRASILEIRO DE GEOGRAFIA E ESTATÍSTICA (IBGE). Censo Demográfico 2010. Rio de Janeiro: IBGE, 2010.

INSTITUTO BRASILEIRO DE GEOGRAFIA E ESTATÍSTICA (IBGE). SIDRA - Censo Agropecuário de 2017. Rio de Janeiro: IBGE, 2017. Disponível em: https://sidra.ibge.gov.br tabela/3939. Acesso em: 7 jan. 2021.

INSTITUTO BRASILEIRO DE GEOGRAFIA E ESTATÍSTICA (IBGE). Produção Agrícola Municipal - PAM. Rio de Janeiro: IBGE, 2018a. Disponível em: https://sidra.ibge.gov.br/ pesquisa/pam/tabelas . Acesso em: 7 jan. 2021.

INSTITUTO BRASILEIRO DE GEOGRAFIA E ESTATÍSTICA (IBGE). Pesquisa da Pecuária Municipal - PPM. Rio de Janeiro: IBGE, 2018b. Disponível em: https://sidra.ibge.gov.br /tabela/3939. Acesso em: 7 jan. 2021.

INSTITUTO BRASILEIRO DE GEOGRAFIA E ESTATÍSTICA (IBGE). Estimativas da População. Rio de Janeiro: IBGE, 2020a. Disponível em: https://www.ibge.gov.br/estatisticas /sociais/populacao/9103-estimativas-de-populacao . Acesso em: 7 jan. 2021.

INSTITUTO BRASILEIRO DE GEOGRAFIA E ESTATÍSTICA (IBGE). Regiões de Influência das Cidades - REGIC 2018. Rio de Janeiro: IBGE, 2020b.

MINISTÉRIO DA AGRICULTURA, PECUÁRIA E ABASTECIMENTO (MAPA). Registro dos estabelecimentos do setor de produção de carne. Disponível em: http://sigsif. agricultura.gov.br/sigsif cons $/ \% 21 \mathrm{ap}$ estabelec nacional rep?p relatorio=estabelecimentos.rdf. Acesso em: 7 set. 2020.

OLIVEIRA, Ariovaldo Umbelino de. Modo de produção capitalista e agricultura. 2. ed. São Paulo: Ática, 1987. 182p. 
RELAÇÃO ANUAL DE INFORMAÇÕES SOCIAIS (RAIS). Número de empregados por setor CNAE 2.0. 2018. Disponível em: <http://bi.mte.gov.br/bgcaged/caged_rais_vinculo_id/login.php>. Acesso em: 7 jan. 2021.

RECEITA FEDERAL. Emissão de Comprovante de Inscrição e de Situação Cadastral. 2020. Disponível em: http://servicos.receita.fazenda.gov.br/Servicos/cnpjreva/Cnpjreva . Acesso em: 7 jan. 2021.

RODRIGUES, M. J.; SILVA, F. B. Considerações teóricas sobre rede urbana. Geoambiente Online, Jataí, v. 8, p. 01-18, 2007.

SANTOS, M. A Natureza do Espaço: Técnica e Tempo, Razão e Emoção. São Paulo: Ed. USP, 1996. 392P.

SECRETARIA DE PLANEJAMENTO, GOVERNANÇA E GESTÃO (SEPLAG); DEPARTAMENTO DE PLANEJAMENTO (DEPLAN). Perfis Socioeconômicos Regiões Funcionais de Planejamento. SEPLAG/DEPLAN: Porto Alegre, 2015. Disponível em: https://planejamento.rs.gov.br/upload/arquivos/201512/15134058-20150319163519perfistodos.pdf. Acesso em: 7 jan. 2021.

SHARMA, S. A ascensão dos gigantes da carne: A indústria extrativa do Brasil. Rio de Janeiro: Fundação Heinrich Böll, 2017. Disponível em: https://br.boell.org/pt-br/2018/04/12/ascensao-dosgigantes-da-carne-industria-extrativa-do-brasil Acesso em: 7 jan. 2021.

SILVA, T. Dália Alimentos em Arroio do Meio adota padrões rigorosos de uso e desinfecção de máscaras. Grupo Independente, Lajeado, 24 abr. 2020b. Disponível em: https://independente. com.br/dalia-alimentos-em-arroio-do-meio-adota-padroes-rigorosos-de-uso-e-desinfeccao-de$\underline{\text { mascaras/. }}$. Acesso em: 10 set. 2020.

SILVEIRA, M. L. Globalização, Trabalho, Cidades Médias. Geo UERJ, Rio de Janeiro, v. 11, p. 11$17,2002$.

SILVEIRA, R. L. L. Complexo agroindustrial do fumo e território: A formação do espaço urbano e regional no Vale do Rio Pardo-RS. 2007. 578 f. Tese (Doutorado em Geografia) - Universidade Federal de Santa Catarina, Florianópolis, 2007.

SINDICATO INTERESTADUAL DA INDÚSTRIA DO TABACO (SINDITABACO). Infográficos. Santa Cruz do Sul: Sinditabaco, 2020. Disponível em: http://www.sinditabaco. com.br/sobre-o-setor/infograficos/. Acesso em: 1 set. 2020.

TRICHES, D.; SIMAN, R. F.; CALDART, W. L. A cadeia produtiva da carne de frango da região da serra gaúcha: Uma análise da estrutura de produção e mercado. In: CONGRESSO DA SOCIEDADE BRASILEIRA DE ECONOMIA E SOCIOLOGIA RURAL, XLIII, Ribeirão Preto. Anais... Ribeirão Preto: USP, 2004.

VOILA, M.; TRICHES, D. A cadeia de carne de frango: Uma análise dos mercados brasileiro e mundial de 2002 a 2012. Revista Teoria e Evidência Econômica, v. 21, n. 44, p. 126-148, 2015. 